\title{
THE FORGOTTEN GEOGRAPHIC AND PHYSICAL - OCEANOGRAPHIC KNOWLEDGE OF THE PREHISTORIC GREEKS
}

\author{
Mariolakos I.D. ${ }^{1}$ \\ ${ }^{1}$ National and Kapodistrian University of Athens, Faculty of Geology and Geoenvironment, \\ Department of Dynamic, Tectonic \& Applied Geology, Panepistimioupoli, Zografou, \\ 157 84,Athens, Greece,mariolakos@geol.uoa.gr
}

\begin{abstract}
Many believe that the Greek Mythology is a figment of the vivid imagination of the ancient Greeks. Consequently, the Greek Myths are all fantastic stories. In my opinion, this view is erroneous, at least on the subject concerning the geographic and physical-oceanographic characteristics of the Atlantic Ocean, as these were described mainly by Homer, Hesiod, the Orphics and Plutarch.

In the present paper ( $i$ ) some of the references made by the above mentioned authors are selectively reported, and (ii) the physical and geological validation is given, based on the present-day scientific views and knowledge.

Namely, the prehistoric Greeks knew about the Hyperboreans, the island of Ierne (Ireland), the British isle etc., by the Orphics.

From the writings of Plutarch, they knew (i) the relative position of the present-day Iceland (Ogygia) and its distance from Britain, (ii) that to the west of Iceland, three other islands are located, where the sun sets for only an hour a day, (iii) that further to the west there is a "great continent", which surrounds the Ocean and more.

Homer and Hesiod wrote that (i) the Ocean is a "river" that flows continuously, (ii) that this river encircles the Earth and (iii) that its flow is turbulent not only on the surface, but in depth as well.

Unfortunately, all this knowledge was gradually forgotten by all. This is the reason why Odyssey is considered just an entertaining poem and Ulysses' nostos a fantastic story, with no trace of historic reality.
\end{abstract}

Key words: Greek Mythology, Cronus, Ogygia, Atlantic Ocean, Oceanus, Gulf Stream, Heracles.

\section{Introduction}

Many believe that the Greek Mythology is a figment of the vivid imagination of the ancient Greeks. Consequently, until the end of the $19^{\text {th }}$ century, all the experts - scientists and especially the archaeologists and the historians, believed that every writing of the ancient authors, such as Hesiod, Plato, Strabo, Diodorus Sicilus and mainly Homer, connected to mythology, lacked even a seed of truth. Consequently, the Greek Myths were all fantastic stories. It was only after the excavations of Schliemann, that it was proven that all of Homer's writings concerning Troy were true, and not only that, but that in Greece, cities like the Mycenae existed and they were the opponents of the Trojans, etc.

Nevertheless, even nowadays, many believe that all included in these writings do not correspond to the 
truth. Our own research, concerning the accuracy of many physical and geological descriptions, given by various ancient authors, and especially by Homer, Hesiod, the Orphics, Diodorus Sicilus, Plutarch and others, has shown that the prehistoric Greeks knew many on the physical-oceanographic characteristics of mainly the Atlantic Ocean. Of course, all the above, for unknown reasons, are not described in a way that are easily understood by everyone, but as a myth, part of the Greek Mythology.

In this paper, the object of the geomythological analysis is the Atlantic Ocean and its relation to the great Titans of Greek Mythology, mainly Oceanus, Atlas, and Cronus.

All these refer to a very old era and in any case, at least to the beginning of the $3^{\text {nd }}$ millennium B.C., until the end of the $2^{\text {nd }}$ one, that is until the end of the Mycenaean period.

\section{Mythological period}

\subsection{General}

The long history of the human being, of Homo sapiens, is divided into two long periods: the historic period, that starts with the invention of writing, and the prehistoric one. The prehistoric period should be further divided into two sub-periods, specifically during the period when Homo sapiens is in the hunting and gathering stage (a food gatherer) and a later one, when Homo sapiens is a food producer, i.e. after the initiation of agriculture and mainly after the cultivation of wheat.

The Mythological period is the prehistoric period that refers to the acts of Gods, deities and heroes, which have not been written down but have remained in the memory of different people, either through tradition, or as it has later been recorded by various authors, but definitely in a very ancient period. These texts constitute the different Mythologies. Such characteristic texts are the Gilgamesh epic, which refers to the people of the Prehistoric Mesopotamia and Hesiod's "Theogony" that represents the Mythology of the Ancient Greeks.

But when we are speaking about Mythology, which is the mythological period or mythological era?

The mythology is always connected to the human. But to which human, to Homo sapiens and/or to Homo neanderthalensis?

We are going to deal mainly with the era of Homo sapiens - not the Homo neanderthalensis (older).

It is undeniable that the borders between myth and reality are vague. Generally speaking, we can say that some of the mythological heroes are historic persons, some others ARE NOT. But, all, or rather NEARLY ALL of them represent something.

I believe that it is a MISTAKE to consider the Greek Mythology as a beautiful fairytale. The Greek Mythology is actually the most ancient history of the peoples who have lived at the land which was later named Hellas (Greece). This land is the Aegean and the peri-Aegean area. The Greek Mythology constitutes the Pre-history of the first Hellenes.

\subsection{What is Geomythology?}

Geo-mythology is a branch of the Geosciences, dealing with the physical-geological conditions during mythological era and, through this to find the interrelation between Geology and Mythology. My experience, as a geologist who has spent his life studying the Geology of Greece, has shown that a great part of the Greek Mythology is indirectly influenced by the physical - geological processes of the Aegean and Peri-Aegean areas. 


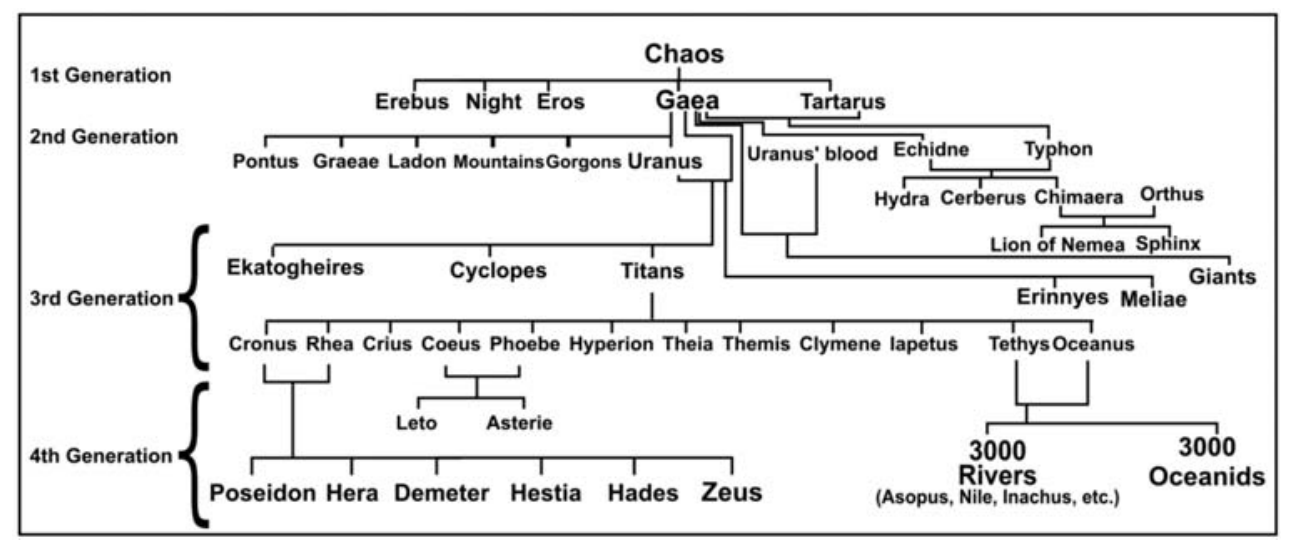

Fig. 1: The genealogy of Gods (4 first generations) according to Hesiod.

The presentation is based on writings of ancient authors AND ONLY ON THESE and mainly on the Ilias and Odyssey of Homer, on the "Theogony" and "Works and Days" of Hesiod, on the Argonautica of Orphics, on Plutarch's (50 - 120 A.D.) Moralia and other well known writers.

The texts of all the above-mentioned authors have been translated, analyzed, commented on, and evaluated mainly by scholars, linguists, poets, historians, archaeologists, art historians, theologists, politicians, both Greeks and foreigners - in other words representatives of humanistic sciences. The result of their efforts? All or almost all of what is about to be mentioned is fantasy $=$ myth .

\section{The Genealogy of Gods}

\subsection{General}

According to the genealogy of gods, demigods, heroes, and the other protagonists of the Greek Mythology, mentioned in Hesiod's Theogeny, the Titans belong to the third generation and they are the offsprings of Gaea (1st generation) and Uranus I(Heaven) (2nd generation).

The six Titans and six Titanesses constituted the first Dodecatheon (twelve Gods), which was replaced by the 12 well known Olympian Gods, the generation of Zeus and Poseidon. It is widely known that this was not a smooth or peaceful replacement, but the result of a war between the Gods of the Cronuse's generation and the one of Zeus. This battle, referred in the Greek Mythology as Titanomachy, resulted in the defeat and the punishment of the Titans, as well as to their exile from Greece, and the Mediterranean Sea, in general.

Three of the most important Titans are Oceanus, Atlas and Cronus (Satturn by the Romans).

Oceanus, according to Hesiod, did not take part in the Titanomachy, but he had already left the Mediterranean with his sister and wife, Tethys, and had gone to the place where the sun sets. This Titan gave his name to the endless sea that surrounds the land of Libya ( = Africa) and Europe, e.g. Ocean $=\Omega$ «qvós.

Atlas, who had lived and had reigned in the central Peloponnesus in Arcadia, and specifically on Mainalon mt., was exiled by Zeus at the north-western part of Africa, on mount Atlas. He was then punished to carry the celestial globe on his shoulders. Atlas gave his name to the neighbouring Ocean, since then known as Atlantic Ocean, as well as to the great island "Atlantis", mention by 
Plato, whose geographical position has been unknown, since it had been destructed by a natural disaster, long before the time of Plato.

Cronus ( = Saturn), the third Titan, was also the Titans' leader during the Titanomachy. It is known that Cronus, along with his sister Rhea, who was also his wife, were the parents of the first 6 great Gods of the $4^{\text {th }}$ generation, namely Poseidon, Hades, Demeter, Hera, Hestia and Zeus.

Cronus is widely known for two of his deeds. The first is that he overturned his father, Uranus, and so he became ruler of the world. The second is that, during his reign and because he had been afraid that one of his offspring would overturn him, ordered his wife Rhea to bring to him every newborn child to eat him or her. But Rhea, both in the case of Poseidon and that of Zeus, managed to cheat Cronus, thus saving her two children. When Zeus, Poseidon and the others grew up to be men, doubted the supremacy of Cronus and so, a long war started between the Titans and the Olympians, known as Titanomachy. Finally, Zeus and the other Olympians defeated the Titans and exiled them to a far place of the west. But where?

\subsection{Cronus after the Titanomachy}

Cronus on the other hand, initially reached Western Europe, on the coast of the Atlantic Ocean and then it seems that he travelled further, firstly to the north and then to the west.

The final place of exile of the leader of the Titans has been described by Plutarch in such a detail that no doubt remains that the prehistoric Greeks of these ancient times had discovered places, which were unfortunately later forgotten. Worth to note that the hero Herculew visited the place of Cronus exile, but much later.

The original greek text of Plutarch, along with its english translation, are given in Fig. 2.

The texts describing these heroic feats is one of the many texts written by the author in his book, entitled "Concerning the Face Which Appears in the Orb of the Moon" and is a part of a great series of texts, know as "Moralia"1.

\begin{tabular}{|c|c|}
\hline 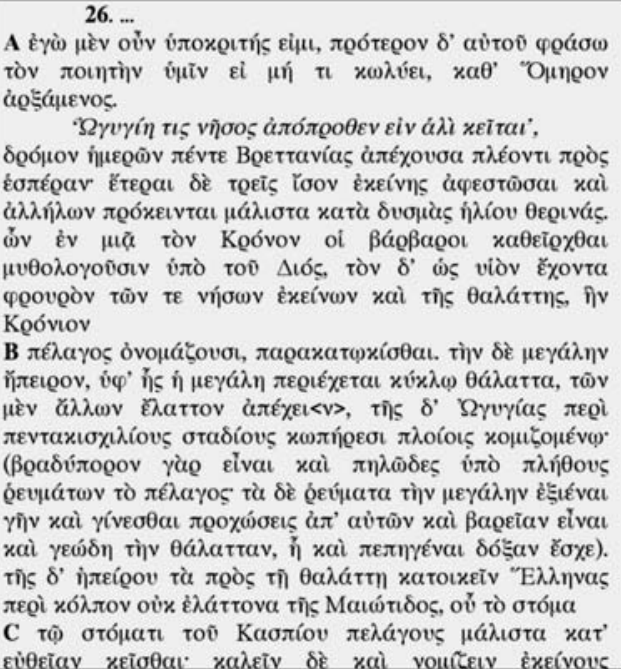 & $\begin{array}{l}26 . . . \\
\text { Almost before I had finished, Sulla broke in. "Hold on, } \\
\text { Lamprias," he said, "and put to the wicket of your discourse } \\
\text { lest you unwittingly run the myth aground, as it were, and } \\
\text { confound my drama, which has a different setting and a } \\
\text { different disposition. Well, I am but the actor of the piece, but } \\
\text { first I shall say that its author began for our sake - if there be } \\
\text { no objection - with a quotation from Homer: } \\
\text { An isle, Ogygia, lies far out at sea, } \\
\text { a run of five davs off from Britain as vou sail westward: } \\
\text { and three other islands equally distant from it and from } \\
\text { one another lie out from it in the general direction of the } \\
\text { summer sunset. In one of these, according to the tale told } \\
\text { by the natives, Cronus is confined by Zeus, and the antique } \\
\text { Briareus, holding wateh and ward over those islands and } \\
\text { the sea that they call the Cronian main. has been settled } \\
\text { close beside him. The great mainland. by which the great } \\
\text { ocean is encircled, while not so far from the other islands, is } \\
\text { about five thousand stades from Ogygia, the voyage being } \\
\text { made by oar, for the main is slow to traverse and muddy as a } \\
\text { result of the multitude of streams. The streams are discharged } \\
\text { by the great land-mass and produce alluvial deposits, thus } \\
\text { giving density and earthiness to the sea. which has been } \\
\text { thought actually to be congealed. On the coast of the }\end{array}$ \\
\hline
\end{tabular}

Fig. 2: Please see next page for continuation and explanation.

\footnotetext{
${ }^{1}$ (both the original text and the transliteration can be easily found on line (see References).
} 


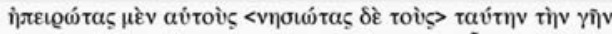

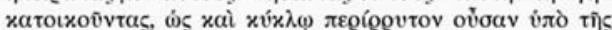

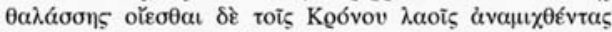

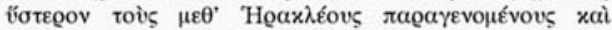

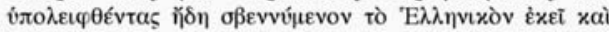

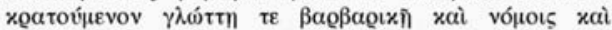

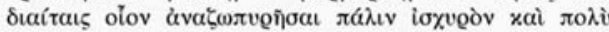

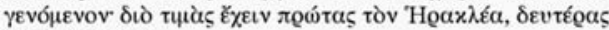

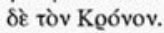

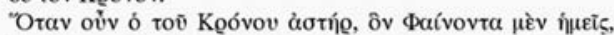

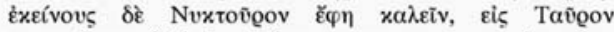

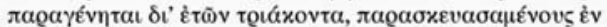

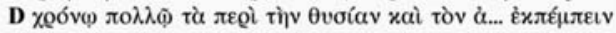

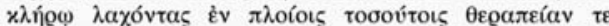

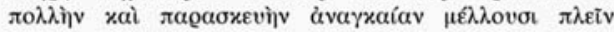

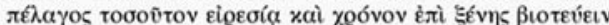

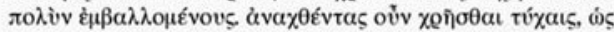

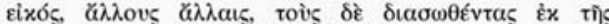

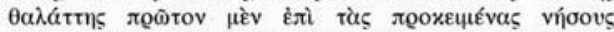

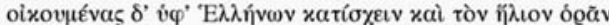

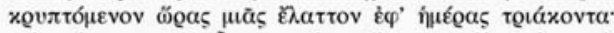

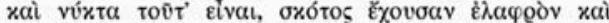
$\lambda v$

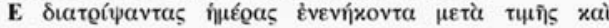

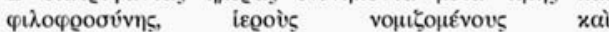

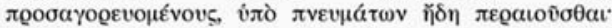

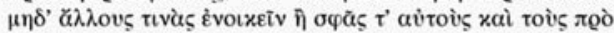
$\alpha$

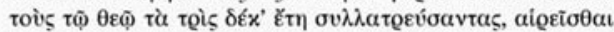

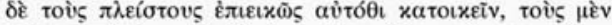

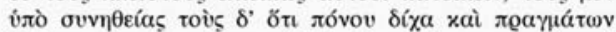

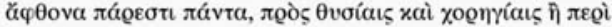
$\lambda$ 'бovs

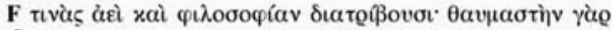

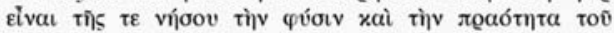

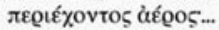

mainland Greeks dwell about a gulf which is not smaller than the Maeotis and the mouth of the Caspian sea ${ }^{1}$. These people consider and call themselves continentals and the inhabitants of this land islanders because the sea flows around it on all sides; and they believe that with the peoples of Cronus there mingled at a later time those who arrived in the train of Heracles and were left behind by him and that these latter so to speak rekindled again to a strong, high flame the Hellenic spark there which was already being quenched and overcome by the tongue, the laws, and the manners of the barbarians. Therefore Heracles has the highest honours and Cronos the second. Now when at intervals of thirty years the star of Cronus, which we call 'Splendent' but they, our author said. call 'Night-watchman.' enters the sign of the Bull, they, having spent a long time in preparation for the sacrifice and the expedition. choose by lot and send forth a sufficient number of envoys in a correspondingly sufficient number of ships. putting aboard a large retinue and the provisions necessary for men who are going to cross so much sea by oar and live such a long time in a foreign land. Now when they have put to sea the several voyagers meet with various fortunes as one might expect: but those who survive the voyage first put in at the outlying islands, which are inhabited by Greeks, and see the sun pass out of sight for less than an hour over a period of thirty days, - and this is night, though it has a darkness that is slight and twilight glimmering from the west. There they spend ninety days regarded with honour and friendliness as holy men and so addressed, and then winds carry them across to their appointed goal. Nor do any others inhabit it but themselves and those who have been dispatched before them, for, while those who have served the god together for the stint of thirty years are allowed to sail off home, most of them usually choose to settle in the spot, some out of habit and others because without toil or trouble they have all things in abundance while they constantly employ their time in sacrifices and celebrations or with various discourse and philosophy, for the nature of the island is marvellous as is the softness of the circumambient air...

'At this point the correct translation of the ancient text is that the Gulf lies on the same line as the mouth of the Caspian Sea.

Fig. 2 cont.: A passage of the original text of Plutarch and its English translation of the book "Concerning the Face which appears in the Orb of the Moon".

From the above mentioned text, anyone can locate the geographical position of the island of Cronus' exile, the travels of the people of Cronus (Cronians), the position of the Gulf of the Great Continent in relation to that of the Caspian Sea, and more.

From this revealing text, we have chosen to present only a few passages, since in such a limited space, it is impossible to refer in detail to all that this great author describes in his book.

Let's see now some of the most important passages of Plutarch's text:

a. "An isle, Ogygia, lies far out at sea, a run of five days off from Britain as you sail westward"

Accepting that vessels similar to Argo (the ship of the Argonauts), could develop speeds approximately $4-5$ miles/hour, then the distance traveled within 5 days must have been in the order of $5 \mathrm{x}$ $24=120$ hours, $120 \times 4 \mathrm{~m} / \mathrm{h}=480$ miles $\approx 900 \mathrm{~km}$ (Fig. 3).

According to these, and using a simple school atlas, Ogygia should correspond to the present-day Iceland. But, concerning the location of Ogygia, there are various viewpoints, such as: a part of Ice- 
land, Greenland, Azores islands (Henriette Mertz), the Bermudas, the small island of Gozo next to Malta, Gavdos isl. south of Crete and Sicily.

Plutarch further informs us:

b. "...three other islands equally distant from it and from one another lie out from it in the general direction of the summer sunset"

Which could these islands be?

If Ogygia corresponds to the present-day Iceland, then the 3 islands located to the west, must be Greenland, New Foundland and Buffin Isl. But their distances from Iceland are not equal.

If the name Ogygia corresponds to the present-day Greenland, then the 3 islands should be New Foundland, Buffin Isl. and Breton Isl. In my opinion, this version is not correct.

c. "...In one of these, according to the tale told by the natives, Cronus (Saturn) is confined by Zeus, and the antique Briareus, holding watch and ward over those islands and the sea that they call the Cronian main, has been settled close beside him..."

If this is so, Cronus should have been confined in one of the three above mentioned islands, i.e. Greenland, Buffin Isl. or New Foundland. Concerning the Cronian main (Sea), a name that has been given by the Hypeboreans, it should be the North Atlantic Ocean (North Sea) and mainly the "cold sea", in other words the Sea that is partly, and from time to time, frozen, that is the Arctic Ocean.

d. "...The great mainland, by which the great ocean is encircled, while not so far from the other islands, is about five thousand stades from Ogygia, the voyage being made by oar, for the main is slow to traverse and muddy as a result of the multitude of streams."

They knew that, west of these islands a mainland existed. But which could this great mainland be? It is obvious that the only great continent, west of the three great islands, which encircles the great Ocean, is the present-day North America. It is important to underline that Plutarch is not only speaking about a land, but about a great continental land ( = $\mu \varepsilon \gamma \alpha \dot{\alpha} \lambda \eta \eta \pi \varepsilon \varrho \omega \tau \iota x \eta ́ ~ \chi \omega ́ \varrho \alpha)$.

e. “...The streams are discharged by the great land-mass and produce alluvial deposits, thus giving density and earthiness to the sea, which has been thought actually to be congealed."

Plutarch continues:

f. "...On the coast of the mainland Greeks dwell about a gulf which is not smaller than the Maeotis and (lies on the same line as) the mouth of the Caspian Sea. These people consider and call themselves continentals and the inhabitants of this land islanders because the sea flows around it on all sides..."

If we take into account that Maeotis is the present-day Azov Sea, and based on a common school geographical atlas, we draw a "straight" line from the "mouth" (that is the northern coast) of Caspian Sea, then we see that the gulf, on the coast of which the Greeks dwell, is the St. Laurence Gulf.

g. "... at a later time those who arrived in the train of Heracles..."

Even Heracles, the great hero of the Mycenaean era, visited this great continent, where Greeks continued to inhabit, even at much later time.

h. "...Now when at intervals of thirty years the star of Cronus, which we call 'Splendent' but they, our author said, call 'Night-watchman,' enters the sign of the Bull, they, having spent a long 


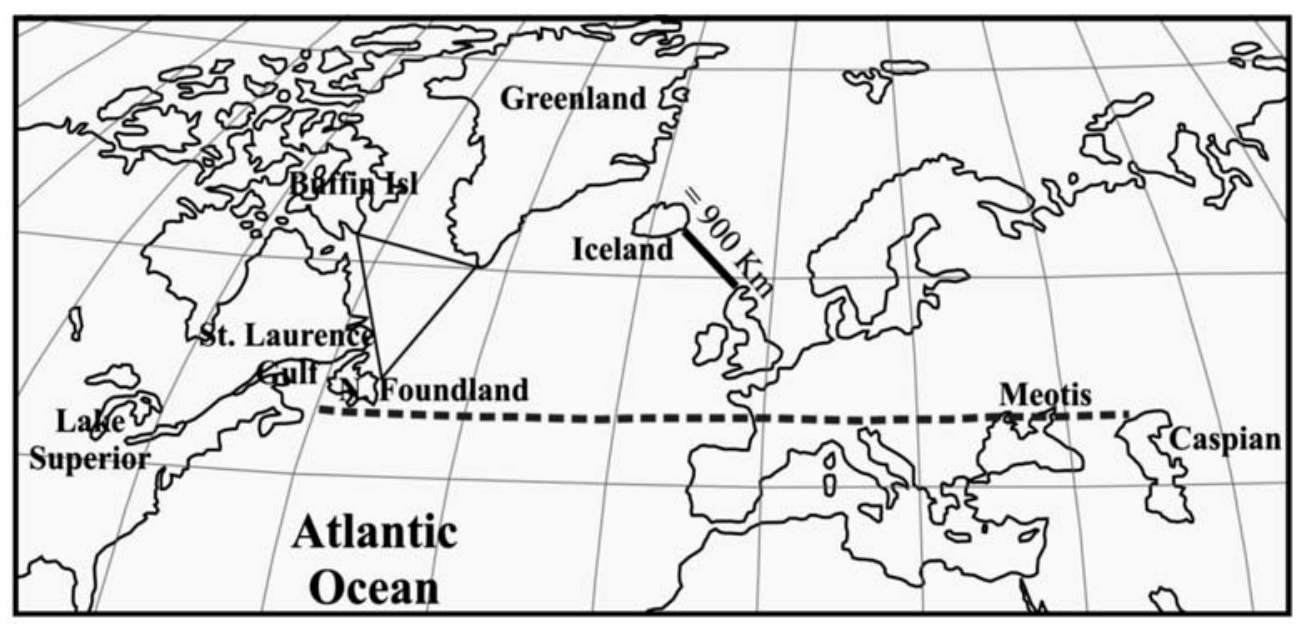

Fig. 3: Map showing the location of the places described in Plutarch's text, the distance between Britain and Ogygia (Iceland), as well as the line (latitude) connecting the entrance of the Caspian Sea and the Gulf of St. Laurence.

time in preparation for the sacrifice and the expedition, choose by lot and send forth a sufficient number of envoys in a correspondingly sufficient number of ships, putting aboard a large retinue and the provisions necessary for men who are going to cross so much sea by oar and live such a long time in a foreign land. Now when they have put to sea the several voyagers meet with various fortunes as one might expect; but those who survive the voyage first put in at the outlying islands, which are inhabited by Greeks, and see the sun pass out of sight for less than an hour over a period of thirty days, - and this is night, though it has a darkness that is slight and twilight glimmering from the west...."

After the above-mentioned, two questions rise, namely: (i) "Where did the prehistoric Greeks know that the sun passes out of sight for less than an hour?" and (ii) "Which islands see the sun "passing out" for less than an hour?"

The answer to the first question is not easy. For sure, Plutarch, who was born in Chaeronia, a small city of the continental Greece, could not have any personal experience. On the other hand, Plutarch later became a priest at the Delphi Oracle. It is throughout possible that he could have been, directly or indirectly, informed by somebody. During these old times, the newly acquired knowledge was restricted mainly among the priests in the temples and in the oracles. The same happened with the priests of Egypt.

But, which are the islands that see the sun "passing out" for less than an hour? It is well known that the Arctic Cycle coincides to the latitude of $66.5^{\circ}$ North. Consequently, the areas, and in this case the islands, which "see the sun passing out for less than an hour" should lie a little to the south of the arctic cycle.

And another important question: Why would they go to North America? What were they after? The answer is that they wanted the native copper, which is found in great quantities in the mines around Lake Superior and on Isle Royale (area of present-day U.S.A. - Canadian borders). This view is validated by archaeological excavation and radiodating of findings ranging from 2,450 - 1,050 B.C., i.e. from the beginning of the Proto-Helladic era, until the fall of the Mycenaean Civilization. 


\section{The knowledge about the Ocean}

\subsection{General}

Let's see now how Homer describes some of the physical and oceanographic characteristics of the Ocean. As it is now accepted, Homer must have lived approximately during the 9th and/or 8th century B.C., while the events he described must have taken place even further in the past, the most recent being the Trojan war and the coming-back of Ulysses.

Homer refers to the Ocean 18 times in the Iliad and 16 times in the Odyssey. Out of all these references, we garner the following:

- "I am going to the world's end to visit oceanus..." (Iliad, XIV) - «...O $\Omega x \varepsilon \alpha v o ́ \varsigma \beta \varrho i ́ \sigma x \varepsilon \tau \alpha \iota$

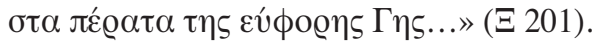

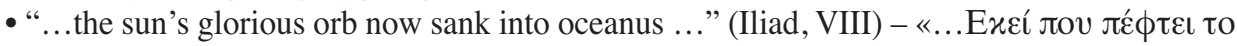

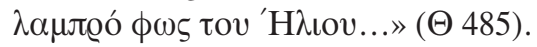

- "... as the sun was beginning to beat upon the fields, fresh-risen from the slow still currents

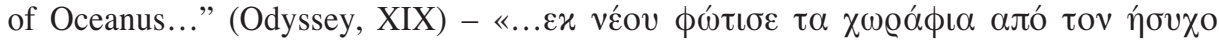
$\beta \alpha \theta u ́ \varrho \varrho o o v \Omega x \varepsilon \alpha$ vóv...» ( $\tau$ 433).

The fact that the sun sets in the Ocean was known, as they have visited again and again the Atlantic Ocean, but how did they know that it also rises from an Ocean? It is well known that to the east of the Aegean area, there are only high mountains. Besides, the Indian Ocean is not located to the east. So, how did they know that the sun rises from the Ocean?

- "(The Earth is surrounded by the) ...ever-encircling waters of Oceanus..." (Iliad, XVIII) - O

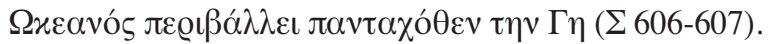

- Oceanus is a great river $\Omega \chi \varepsilon \alpha v$ ós that stretches to the 4 points of the horizon.

- "...By the flow of the Ocean, towards the west, lies Hades (Odyssey, XIX) and beyond the Elysium plains ...” - “...

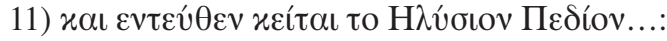

Analyzing all the above, we conclude that the Ocean is not a "wide sea", as the Mediterranean or the Red Sea. On the contrary, the Ocean is considered to be a great river, which means that it does not surround the Earth statically, but dynamically, as it flows like a river. Besides, the etymology of the word $\Omega x \varepsilon \alpha v o ́$ (Oceanus) in ancient greek, shows this perpetual movement of the river Oceanus. The word $\Omega$ xavós (Oceanus) is the result of the word " $\Omega x v ́ \varsigma$ " which means "quick" and " $v \alpha \dot{\omega} \omega$ " which means flow. So, the very word $\Omega x \varepsilon \alpha v$ ó 5 - Oceanus means quick flow.

Another group of texts that refer to the Ocean and its physical and oceanographic characteristics is the Orphic texts. From the Orphics Argonautica and the orphic hymns, we garner the following:

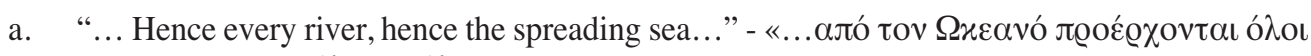

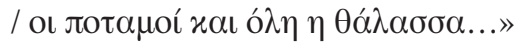

Consequently, the Ocean is compared to the sea. The sea, in this case, is certainly the Mediterranean Sea.

b. "OCEAN I call, whose nature ever flows, From whom at first both Gods and men arose;/ Sire incorruptible, whose waves surround, / And earth's concluding mighty circle bound..." (From

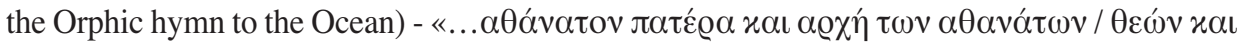

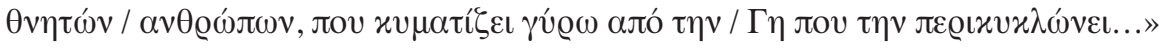

c. "...Old Ocean too ..., / Whose liquid arms begirt the solid land..." (From the Orphic hymn to

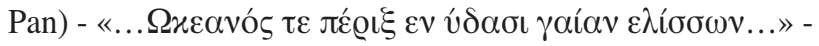


The poet Hesiods, in his work "Theogony" refers to the Ocean, as:

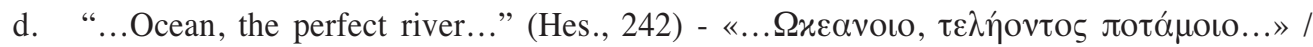

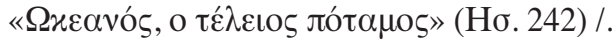

\subsection{Characteristics of the Ocean river}

Let's see now, how the special characteristics of the flow of the river Ocean, i.e. of the current, are described.

Hesiod refers to the Ocean as $\alpha \psi o ́ \varrho o o$ (back-flowing). This characterization has been render as "swaying", in modern greek. This means that the ocean water perform a "reversible movement", i.e. a movement along an axis. In my view, this interpretation is not accurate, since the ancient greek

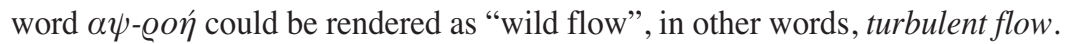

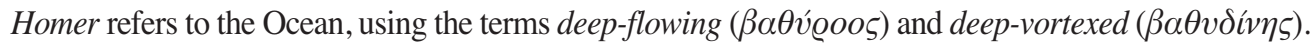
Deep-flowing means that the river Ocean flows not only on the surface, but also in depth, and this deep flow is not laminar but turbulent, that's why the Ocean is also characterised as deep-vortexed ( $\beta \alpha \theta v \delta i v \eta \varsigma)$.

Today, we know that the oceanic currents extend to a depth of about $800-1200 \mathrm{~m}$. and that up to that point their flow is turbulent. In recent times, this has been verified with the use of different instruments that allowed the simultaneous measurement of the flow velocity as well as the depth.

But, at the time of Homer, how could anyone know that the river Ocean displays a turbulent flow both on the surface and in depth?

Generally speaking, all the knowledge about the Ocean was forgotten. Even after the discovery of America, nothing is mentioned about the currents, despite the fact that the fishermen of the Ocean must have known them, but for different reasons, they preferred not to speak about them.

\section{The forgotten knowledge}

All this knowledge was acquired during the time period between the beginning or the middle of the $3^{\text {rd }}$ millennium B.C. and the end of the Mycenaean era, i.e. around the end of the $2^{\text {nd }}$ millennium, about $100-150$ years after the Trojan War.

This is concluded by the texts left mainly by the Orphics, Homer, Hesiod and Plutarch, who is much younger $(50-120 \mathrm{AD})$.

It is well known, the fall of the Mycenaean empire was followed by an era, known as dark ages. During this period a lot of the knowledge acquired by the prehistoric Greeks, for unknown reasons, was lost.

Consequently, and despite the fact that the Greeks of the historical times managed to create the wellknown Greek Civilisation which peaked during the $5^{\text {th }}$ century B.C., nevertheless they ignored the Ocean. It is strange that, while they created colonies, they developed the commerce and the seafaring, they had conquests, they developed the architecture, the poetry, the theatre etc., they forgot all about the river Ocean, they forgot the Cronian Sea, they forgot about Ogygia and the islands where the sun sets for only an hour per day, for the duration of a month etc.

All these were forgotten, and they were also forgotten by Alexander the Great, by the Romans, but also later by the Christians.

The only exception is Pytheas of Massilia (approx. 380 -310 B.C.), who left Marseille and after 


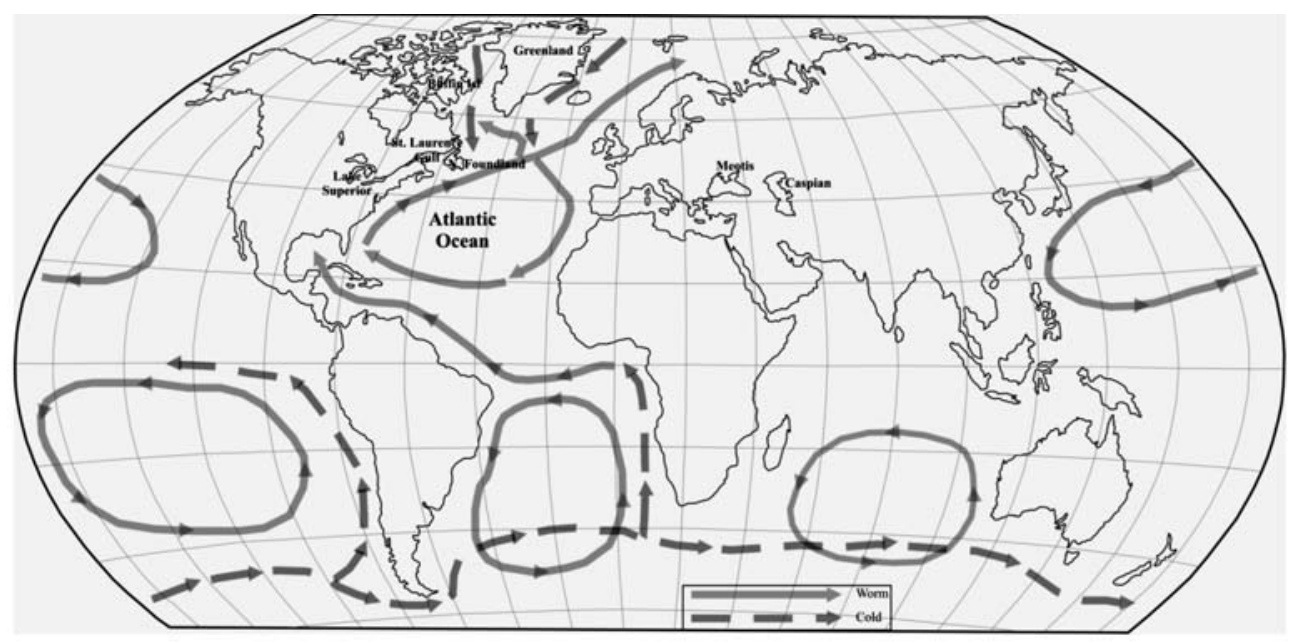

Fig. 4: Generalized map showing the ocean currents circulation (continuous lines: warm currents, dashed lines: cold current).

reaching Britain and Ierne (Ireland), he arrived at Thule, which is said to be the present-day Iceland. From there, Pytheas must have arrived in the arctic area and then he must have returned to Massilia.

Consequently, most of the ancient people, including the Phoenicians, must have travelled in the Ocean, but never far from the European coasts. The fact is of course that the book "About the Ocean"

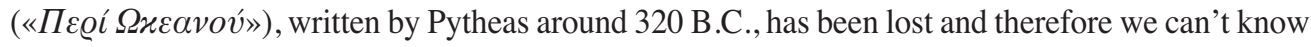
exactly up to which point he managed to go.

\section{The discovery of the Gulf Stream}

All the above-mentioned were re-discovered at least 3,000 years later, around the $16^{\text {th }}$ century AD, when Ponce de Leon first described the "Florida Current" (1513).

After this, an effort of studding the Atlantic Ocean currents has started. An intensive study of the Gulf Stream begun during the second half of the 18th century. The occasion was a letter sent by Benjamin Franklin, (then Postmaster General of the North American Colonies) to captain Folger, asking him to make a chart of Gulf Stream, in order to make the postal delivery from England faster.

By the end of this century, several maps were constructed, among them temperature maps, after detailed and systematic temperature measurements.

The first maps of the area refer to the Gulf Stream as "Gulf of Florida", or as "Florida Straits", or "Bahama channel". The name "Gulf Stream" appeared for the first time in 1842, on a map by Sydney Morris and Samuel Breese.

The systematic observations begun actually in 1845, while Mathew Maury, in his book «Physical Geography of the Sea» (1855) wrote:

"There is a river in the ocean. In the severest droughts it never fails, and in the mightiest floods it never overflows....Its current is more rapid than the Mississippi or the Amazon...»,

Compare the above passage to that of Homer ( $8^{\text {th }}$ (?) cent. B.C.): 


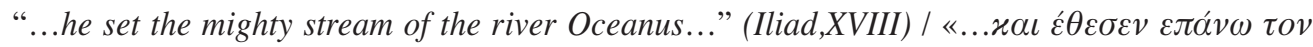

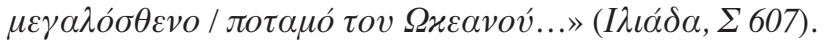

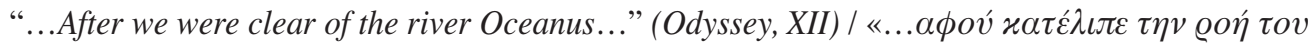

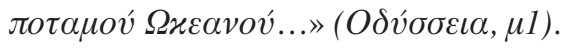

From the recent research activity of the scientific community, the results we' re interested in are the ones referring to the meanderisms of the current, as well as the location of gyres and warm core eddies. It's a research effort that begun during the seventies, with the utilization of modern space applications. These applications verify the knowledge - legacy of the Orphics, Homer and Hesiod, Plutarch, Ovid and others. In other words, it is verified that:

- The Ocean is a great river that surrounds the Earth (then considered a disc), as it was depicted on the shields of Hercules and Achilles.

- The Ocean is back-flowing ( $\alpha \psi o ́ \varrho o o \varsigma, ~ o \pi \iota \sigma \theta o ́ \varrho o o \varsigma)$.

- The Ocean is deep-flowing ( $\beta \alpha \theta$ v́@@oos).

- The Ocean is deep-vortexed $(\beta \alpha \theta v \delta i v \eta \varsigma)$.

\section{Discussion - conclusions}

Summarising all the above mentioned, taken of the writings of two great poets, and mainly (a) Homer's Iliad and Odyssey, (b) Hesiod's Theogony and Works and Days, (c) Orphics' Argonautica and (d) Plutarch's Moralia, we can assert that the prehistoric Greeks, already as far back as the times of Titan Cronus, up until the times of Hercules and Ulysses, should had known plenty of the presentday Atlantic Ocean and its islands, as well as the lands located beyond the Pillars of Hercules.

According to the writings of Plutarch, the prehistoric Greeks should have known the following:

(i) Britain and Ierne (Ireland).

(ii) Iceland, which is mentioned as Ogygia, its relative position to Britain and the distance between the two islands.

(iii) The three islands located west of Ogygia (Iceland), which should be the present-day islands of Greenland, Buffin Island and New Foundland.

(iv) That the three above-mentioned islands are equidistant.

(v) He refers to the "Cronian Main (Sea)" that, according to the Orphics, is the name given by the Hyperboreans to the present-day North Atlantic Ocean and a part of the Arctic Ocean.

They also knew:

(vi) That at the west of these three islands there was a great mainland (a great continental country) that encircles the great Sea.

(vii) That the coast of a gulf on this great continent was inhabited by Greeks.

(viii) That the size of the above-mentioned gulf is approximately the same as that of the Maeotian Sea (present-day Azov Sea).

(ix) That this gulf is located "on the same straight line" as the mouth of the Caspian Sea. This means that the northern coast of the Caspian Sea are located on the same latitude as the gulf located on the great mainland (great continent). After this detailed definition, there really must be no doubt that this gulf should be the St. Laurence Gulf of the present-day Canada, and consequently the "great mainland" is North America.

(x) They also knew that sea-currents exiting from the above-mentioned gulf towards the Atlantic carried argillaceous material ("earthiness") that obstructed the sailing of the ships, that's why 
the sailors, as they could not use the sails, they sailed by oars.

(xi) That the people that arrived there with Hercules, stayed in an area on one of the three islands, where the sun only set for one hour, for a period of 30 days.

Taking into consideration all the above-mentioned, one can indirectly draw more, concerning the knowledge of the prehistoric Greeks, beyond the confirmation of what is mentioned by Plutarch. These indirect conclusions are the following:

(i) That they knew how to measure great surfaces, i.e. the surface of the Azov Sea (Maeotis) and that of the Gulf of St. Lawrence.

(ii) That the discovery of Iceland, of the three islands and that of the great mainland, must have taken place, according to the most conservative assessment, approx. at the beginning of the $3^{\text {rd }}$ millennium B.C., i.e. at the start of the Proto-Helladic era.

(iii) That they knew the way to determine the latitude of a given area.

(iv) That long before the time of Hercules and the Argonauts, even before the time of Phrixus and Elle, they knew the Caspian Sea, the Hyperboreans, the Rippean mountains, the Sarmatian Sea (Baltic Sea), the different rivers like the Dneiper (which they called Vorysthenis), Don (Tanais) etc., as well as the people who lived in the areas between the Euxenian Pontus and the Baltic Sea (Sarmatian Sea).

Concerning the knowledge about the Ocean, based on Homer's works, Iliad and Odyssey, and those of Hesiod, the conclusions are the following:

(i) Oceanus is a great river that stretches to the four points of the horizon. That means that Oceanus doesn't surround the Earth statically, but dynamically, as it flows like a river.

(ii) The Earth is surrounded by the "...ever-encircling waters" of Oceanus (Il., $\Sigma$ 606-607).

(iii) "...Old Ocean too ..., / Whose liquid arms begirt the solid land" (after Orphic Hymn to the god Pan).

Based on the above mentioned, it is clear that they knew about the Ocean currents, not only those of the Atlantic Ocean, but of all the Oceans, as “...the great river stretches to the four points of the horizon...".

Taking into account all the above mentioned, the following question is posed:

Is it possible for someone (or more) to describe all these places and all these physical and oceanographic characteristics, if they had not visited the area or crossed the Ocean?

Let me remind you that we refer to the time period between the beginning of the $3^{\text {rd }}$ Millennium and the end of the $1^{\text {st }}$ Millennium B.C.

\section{References}

Hesiod. Theogony.

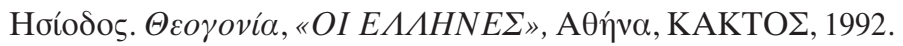

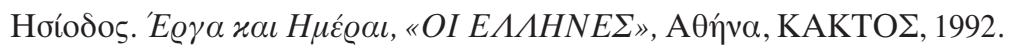

Homer. Iliad.

Homer. Odyssey.

Mariolakos, I., 2004. Geomythology. In Birx, J., H. (Ed.), Encyclopedia of Anthropology, vol. 3, 10661071, New York, SAGE Publ.

Mariolakos, I., Kranioti, A., Marketselis, E., Papageorgiou, M., 2007. Water, mythology and environ- 
mental education, Desalination, 213/1-3, 141-146.

Maury, M. F., 1855. The Physical Geography of the Sea. New York, Harper \& Brothers, Publishers. 287pp. Available online at: http://books.google.gr/books?id = Z5jN3YpoOjgC\&printsec $=$ frontcover $\& \mathrm{dq}=$ physical + geography+of + the + sea $\& \mathrm{~cd}=3 \# \mathrm{v}=$ onepage $\& \mathrm{q}=\& \mathrm{f}=$ false

Mertz, H. 1964. The Wine Dark Sea: Homer's Heroic Epic of the North Atlantic (Greek translation by Zairis, NEA THESIS publ., 1995).

Mertz, H. 1976. Atlantis: Dwelling Place of the Gods (Greek translation by Zairis, NEA THESIS publ., 1999).

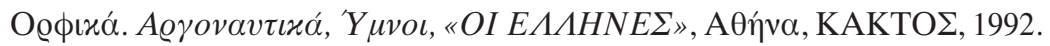

Plato. Kritias.

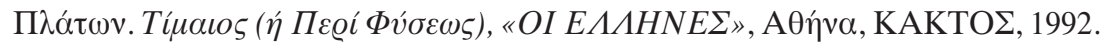

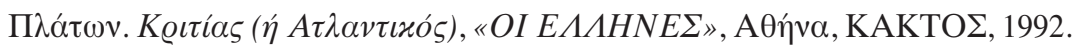

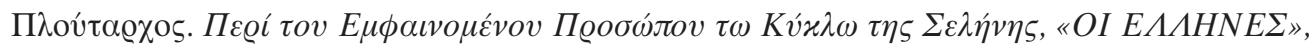
A $\theta \dot{\eta} v \alpha, \mathrm{KAKTO} \Sigma, 1996$.

Plutarch. Moralia, Concerning the Face which appears in the Orb of the Moon. Available online at: http://www.mikrosapoplous.gr/anc_texts/texts_plut.htm (Greek text), and http://penelope.uchicago.edu/Thayer/E/Roman/Texts/Plutarch/Moralia/The_Face_in_the_Moon*/D.html) (English text). 